\title{
The role of probiotics in times of the COVID-19 pandemic
}

\section{El papel de los probióticos en tiempos de la pandemia COVID-19}

\author{
LARA-LÓPEZ, Ivonne Montserrat†, SANTIESTEBAN-LOPEZ, Norma Angélica*, CERÓN- \\ CARRILLO, Teresa Gladys and MORALES-PAREDES, Yesbek Rocío
}

Universidad de Guadalajara. Centro Universitario de Ciencias Exactas e Ingenierías. Jalisco, México.

ID $1^{\text {st }}$ Author: Ivonne Montserrat, Lara-López

ID $1^{\text {st }}$ Couthor: Norma Angélica, Santiesteban-López / ORC ID: 0000-0001-7700-4139, CVU CONACYT ID: 240825

ID $2^{\text {nd }}$ Coauthor: Teresa Gladys, Cerón-Carrillo / ORC ID: 0000-0002-3492-379X, CVU CONACYT ID: 211348

ID $3^{\text {rd }}$ Coauthor: Yerbek Rocío, Morales-Paredes / ORC ID: 0000-0003-1740-2682, CVU CONACYT ID: 296456

\begin{abstract}
In December 2019, cases of a life-threatening pneumonia-producing disease were reported in Wuhan, China (COVID-19). There is not yet a vaccine or scientifically proven treatment at the moment. WHO recommends: washing hands, covering nose and mouth, correct cooking of food, avoiding close contact with anyone. Nowadays, individuals are interested in consuming foods that, apart from their nutritional value, additionally benefit as preventing diseases, that is why the consumption of probiotics originates a marked interest in Lactic Acid Bacteria (LAB) and their metabolites. Since when ingested, changes occur in the intestinal microflora and have a positive impact on the health status of the consumer. The intestine plays a very important role that has an impact on our tolerance and defense mechanism against diseases, concluding with the fact that by maintaining a better balance in our intestinal microbiota, our entire immune system will be strengthened, thus avoiding contagion by the current virus. It closed with a pilot survey in which it is inferred that most people are willing to consume probiotics to increase their defenses.
\end{abstract}

\section{COVID-19, Probiotics, Immune system}

\begin{abstract}
Resumen
En diciembre del año 2019, se informó de casos de una enfermedad productora de neumonía potencialmente mortal en Wuhan, China (COVID-19). No existe aún vacuna ni tratamiento científicamente probado por el momento. La OMS recomienda: lavarse las manos cubrirse nariz y boca, cocción correcta de alimentos, evitar el contacto cercano con cualquier persona. Hoy en día, los individuos están interesados en consumir alimentos que, aparte de su valor nutricional, beneficien adicionalmente como prevenir enfermedades, es por eso que el consumo de probióticos origina un marcado interés por las Bacterias Ácido Lácticas (BAL) y sus metabolitos. Ya que al ingerirse ocurren cambios en la microflora intestinal y repercuten positivamente en el estado de salud del consumidor. El intestino desempeña un papel muy importante que tiene impacto en nuestro mecanismo de tolerancia y defensa ante enfermedades, concluyendo con el hecho de que manteniendo un mejor balance en nuestra microbiota intestinal, todo nuestro sistema inmunológico se verá fortalecido, evitando así el contagio por el actual virus. Se cerró con una encuesta piloto en la cual se infiere que la mayoría de las personas están dispuestas a consumir probióticos para aumentar sus defensas.
\end{abstract}

COVID-19, Probióticos, Sistema Inmunológico

Citation: LARA-LÓPEZ, Ivonne Montserrat, SANTIESTEBAN-LOPEZ, Norma Angélica, CERÓN-CARRILLO, Teresa Gladys and MORALES-PAREDES, Yesbek Rocío. The role of probiotics in times of the COVID-19 pandemic. ECORFAN Journal-Republic of Guatemala. 2020, 6-10: 12-23

\footnotetext{
* Correspondence to Author (email: asantiesteban2@ @otmail.com)

$\dagger$ Researcher contributing first author.
} 


\section{Introduction}

In December 2019, a rapidly spreading pneumonia represented a global threat, which emerged and was known as COVID-19 (an acronym for coronavirus disease 2019) and emerged in Wuhan, China. So far, this has been the third zoonotic coronavirus outbreak in the past twenty years, allowing for person-to-person transmission and raising concerns about global health (Xie \& Quiong, 2020). Prevention measures include constant hand washing, use of face masks, and avoiding contact between people (Palacios-Cruz, 2020). Each of the measures must be adopted and put into practice by the population every day, which is also in charge of not only keeping this information, but also that each individual seeks prevention and control alternatives for the disease in question.

The main objective is to strengthen the immune system and although the disease (Covid-19) appears to be asymptomatic or paucisymptomatic in most cases, we do not have effective therapeutic resources to combat it, so we are constantly searching for alternatives. for example the use of probiotics in the human diet; There is no evidence that probiotics can help prevent, but there is a study that found that some probiotics reduce the incidence of common respiratory infections in children and the elderly (Lenoir-Wijnkoop et al. 2019). Therefore, even without scientific evidence, we can consider and discuss the possible benefits of probiotics in situations like the current one.

\section{Coronavirus (COVID-19).}

In December 2019, a rapidly spreading pneumonia represented a global threat, which emerged and was known as COVID-19 (an acronym for coronavirus disease 2019) and emerged in Wuhan, China. So far, this has been the third zoonotic coronavirus outbreak in the past twenty years, allowing for person-to-person transmission and raising concerns about global health. As of March 11, 2020, there were 80,955 confirmed cases and 3,162 deaths in China, as well as 37,364 confirmed cases and 1,130 deaths worldwide (Xie \& Quiong, 2020). Of course, the information has been spreading and in a matter of days the pertinent measures were taken to subject the populations to a quarantine period, in order to avoid the spread of the virus.
Coronaviruses are a large family of viruses of positive sense single-stranded RNA genetic material, they have envelopes, they are highly diverse (Figure 1A) and are called "coronaviruses" due to the corona shape they present in their structure. These viruses are grouped into four genera: Alphacoronavirus, Betacoronavirus, Gammacoronavirus, and Deltacoronavirus. In the last seventeen years, two of the group of Betacoronaviruses have been of great interest to the scientific community and to world health: the cause of severe acute respiratory syndrome (known as SARS-CoV) and the cause of the Middle East respiratory syndrome (known as MERS-CoV). Both SARS$\mathrm{CoV} 2$ and MERS-CoV2 are known to be of zoonotic origin (Cortés. 2020), which means a zoonosis; known as any disease that can be transmitted from animals to humans.

The word is of Greek origin, zoon which means animal and nosos disease. Animals that transmit zoonotic viruses are usually vertebrates, for example, bats and palm civets in the case of SARS-CoV, as are camels and dromedaries in the case of MERS-CoV (Figure 1B).

Human and avian flu, SARS-CoV and MERS-CoV were ruled out, so it was reported that the coronavirus responsible for the outbreak in Wuhan is a group 2B Betacoronavirus. With a genetic sequence at least $70 \%$ similar to SARS$\mathrm{CoV}$, the WHO named it SARS-CoV-2 (initially 2019-nCoV-2). The pathology that it produces is called coronavirus disease "COVID-19" (Cortés. 2020). The natural reservoir for SARS-CoV-2 is believed to be bats, with snakes or other animals as intermediaries.

However, the route of transmission to humans at the beginning of this event remains unclear. Bats are rare in markets in China, but they are hunted and sold directly to restaurants. The most likely current hypothesis is that an intermediate host animal has played a role in transmission. Both Chinese and external expert groups are working to try to accurately identify the animal source of this new virus (OMS. 2020). 


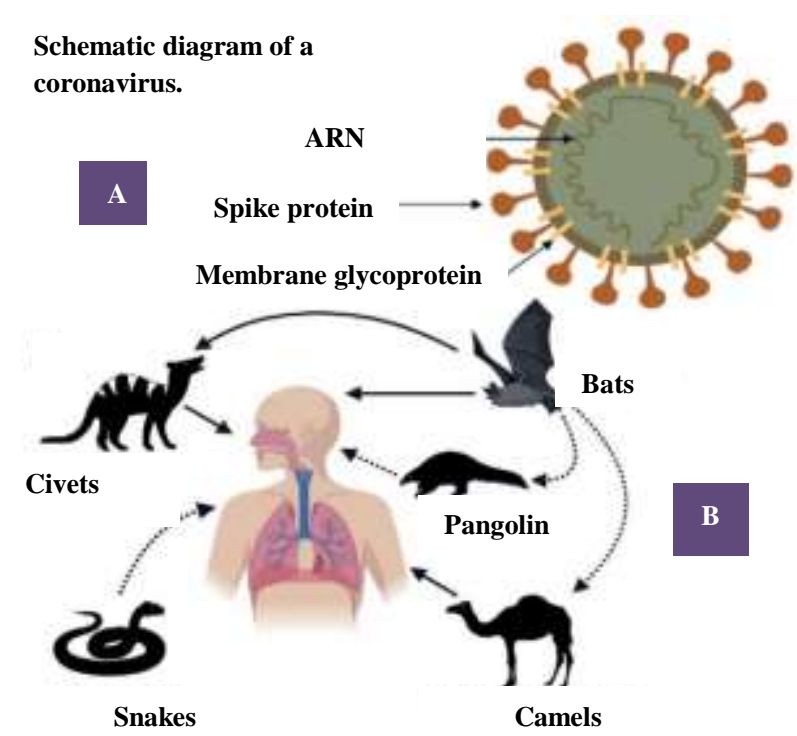

Figure 1 A: Schematic diagram of a coronavirus. B: Zoonotic transmission

Source: (Cortés, 2020)

The typical symptoms associated with this infection includes fever, asthenia and dry cough, with a acute respiratoy in the most serious patients and with alveolar damage secondary to a massive release of pro-inflammatory molecules (Alcántara-Montero, 2020). However, there is a population that does not present symptoms or these are imperceptible, the so-called asymptomatic.

The asymptomatic patient represents an important source in the spread of the virus. Identifying and monitoring asymptomatic cases is of vital importance, although this type of patient cannot present any symptoms during the detection of COVID-19, the patient's period of being transmissible lasts for three weeks.

This is the importance of considering asymptomatic people as a source of COVID-19 transmissibility and of monitoring these types of patients to avoid outbreaks and possible collapses of health services (Rojas-Zumarán et al. 2020).

The emergence of the current SARSCoV-2 pandemic seems to have come with some surprise. However, epidemics or pandemics have been present throughout history (Figure 2).

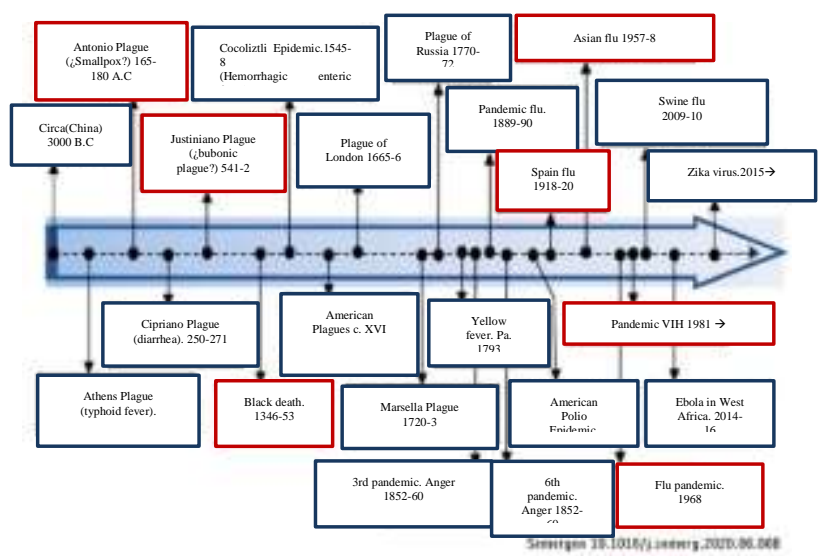

Figure 2 Timeline of pandemics throughout history Source: (Serrano-Cumplido et al. 2020)

\section{Characteristics of the disease}

It is true that around the world, emerging and reemerging infectious diseases are challenges we face. This time, the new type of Coronavirus (2019-nCoV), which are capable of causing respiratory, enteric, liver and neurological diseases. So far, six known species of this viral group are known to make humans sick. Four of these (229E, OC43, NL63, and HKU1) cause common flu symptoms in immunocompetent people, and two species of current interest (SARS-CoV and MERS-CoV) cause severe acute respiratory syndrome and represent high mortality rates.

Complete analyzes of the virus genome were carried out with bronchoalveolar lavage, whole genome sequencing, PCR test and culture in hospitalized patients in Wuhan, China; Likewise, thanks to these studies, the infection by 2019-nCoV was confirmed. Based on the infected patients, the pertinent information was collected, they manifested with significant signs and symptoms: fever (98\%), dry cough $(76 \%)$, dyspnea (55\%), myalgia or fatigue $(44 \%)$ and lymphopenia ( 63\%) (Silva Belasco \& Dezoti da Fonseca, 2020).

It can be rescued with this context that respiratory secretions would be the main means of contagion and spread of the virus. This disease is characterized by being of low lethality, around $3 \%$ but with high transmissibility, although with a low lethality of around 3\%, the transmissibility is high (Palacios-Cruz et al. 2020). Regarding the susceptibility of contagion, the new coronavirus can infect any person or individual can have mild to severe symptoms. 
Although the elderly, asthmatics, diabetics and people with heart disease are more vulnerable and can become seriously ill with the virus, thus reporting a mortality rate $>8 \%$ in people older than 70 years.

\section{Clinical tests}

Laboratory diagnosis is among the top priorities to facilitate public health interventions in patients. When it comes to an acute respiratory infection, RT-PCR is commonly used to identify viruses that are causing respiratory secretions. The test to detect the viral envelope gene sequence has been effectively implemented, however, the diagnostic algorithm uses other sequences of the viral genome to confirm positivity for 2019-nCoV by detecting sequences of the viral RNA polymerase gene and the Nucleoprotein.

Other samples to collect are:

Extraction of RNA from clinical samples
with the MagNA Pure 96 System.
Respiratory material (nasopharyngeal
and oropharyngeal swab in outpatients
and sputum [if present] and / or
endotracheal aspirate or bronchoalveolar
lavage in patients with severe respiratory
disease).
Serum for serological tests, acute sample
and convalescent sample (additional to
respiratory materials) (Palacios-Cruz,
2020).

\section{Prevention measures}

The WHO dictates standard recommendations to prevent the spread of infection include: washing hands regularly, especially after contact with sick people or their environment, covering the mouth and nose when coughing and sneezing, correct cooking of foods such as meat and eggs, avoid close contact with anyone showing symptoms of respiratory illness (coughing and sneezing), avoid travel to affected cities and areas, and avoid close contact with live or dead farm or wild animals. For travelers with symptoms of acute respiratory infection, they should practice cough etiquette (keep their distance, cover their mouths when coughing and sneezing with tissues or clothing, and wash their hands properly).
Those who have had contact with patient cases that have been classified as probable or confirmed of 2019-nCoV should be monitored for 14 days from the last contact they had with them without protection and should limit transfers to places outside their place of study. residence to avoid possible spread.

One of the most used preventive measures is the use of face masks. Surgical masks for the public are not $100 \%$ effective protection against airborne viruses or bacteria, since they do not have an adequate air filter and leave the eyes exposed, and although they could help reduce the risk of contracting the viruses through sneezes or coughs of others, the optimal is the use of respirators that have a specialized air filter, since they are specifically designed to protect a person against potentially dangerous particles that are in the air, for example the FFP masks ( Palacios-Cruz, 2020).

Each of the measures must be adopted and put into practice by the population every day, which is also in charge of not only keeping this information, but also that each individual seeks prevention and control alternatives for the disease in question.

The main objective is to strengthen the immune system and as the years go by, the pharmaceutical industries have worked hard in the research, formulation and experimentation of drugs capable of promoting a good result in the improvement of public health, as well as vaccines., supplements, tablets, syrups, etc. and although the disease (Covid-19) appears to be asymptomatic or paucisymptomatic In most cases, we do not have effective therapeutic resources to combat it, so we are constantly searching for alternatives, for example the use of probiotics in the human diet;

There is no evidence that probiotics can help prevent, but there is a study that found that some probiotics reduce the incidence of common respiratory infections in children and the elderly (Lenoir-Wijnkoop et al. 2019), they also prevent infectious diarrhea in areas endemic, and prevent and shorten the duration of rotavirus diarrhea, also reducing fecal shedding and virus shedding (Guarner,. 2020). Therefore, even without scientific evidence, we can consider and discuss the possible benefits of probiotics in situations like the current one. 


\section{Probiotics}

Over a hundred years ago, Elie Metchnikoff, a Russian Nobel Prize-winning scientist, posited that LABs were beneficial to health, and had the ability to promote longevity. He then suggested that the gut microbiota could be enhanced by "gut autointoxication" and thus the resulting aging could be suppressed by modifying it and replacing proteolytic microbes, which produce toxic substances with useful microbes. He designed a diet with milk fermented with a bacteria that he named "Bulgarian Bacillus." This concept continued to evolve.

Often times, intestinal tract disorders were treated with viable non-pathogenic bacteria to modify or replace the intestinal microbiota. In 1917, German scientist Alfred Nissle isolated a non-pathogenic strain of Escherichia coli from the feces of a World War I soldier. That strain turned out to be Escherichia coli strain Nissle 1917 , and it is one of the few examples of a probiotic that is not BAL. Henry Tissier (from the Pasteur Institute) isolated a Bifidobacterium from a breastfed infant for the purpose of administering it to infants suffering from diarrhea. His hypothesis was that this germ would displace the proteolytic bacteria that cause diarrhea. In Japan, Dr. Minoru Shirota isolated the Shirota strain of Lactobacillus casei to deal with outbreaks of diarrhea.

There is a probiotic product with this strain that has been in the market since 1935 . These were the first predecessors in a scientific field that has flourished throughout history. Today, there are endless articles and essays on probiotics. Accumulating evidence supports the view that benefits are measurable across many parameters (Gastroenterology, 2017). Throughout the investigations, it has been tried to modulate the intestinal microbiota for the benefit of the host, so probiotics have been used, which must meet certain characteristics such as safety, that they stay alive and colonize the intestine, among others.

There are different products from the food and pharmaceutical industries that contain probiotics in their composition: oral rehydration solutions, infant formulas and food. Many of them do not contain only one strain, but are combinations of several species of microorganisms, there are even some also associated with vitamins and prebiotic substances.
LABs have been present in our diet for centuries since they are found in fermented milk products such as yogurt, jocoque, matured cheeses, meat products and even in some vegetables (Figure 3 ).

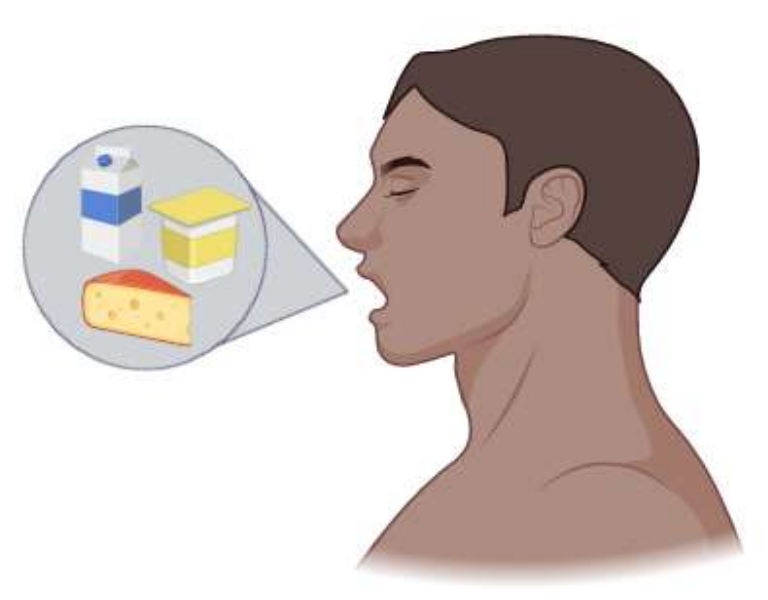

Figure 3 Intake of foods containing probiotics

Source: Own elaboration with data from: https://biorender.com/

Probiotics are living microorganisms that, when ingested in adequate amounts, exert a positive influence on the health or physiology of the host. The term "probiotic", etymologically, comes from the Greek "pro bios" (for life). The most frequent way of consuming probiotics is through dairy foods that contain intestinal species of lactobacilli and bifidobacteria, due to the beneficial effects in addition to the nutritional ones, these foods are considered in the group of functional foods.

Once the probiotics are ingested, changes occur in the intestinal microflora that have a positive impact on the consumer's state of health. It is important to highlight that the intestinal flora (Figure 4) is an interactive community of organisms with specific functions to maintain the state of health.

This function is the sum resulting from the different combined activities of the organisms that make it up, such as the fermentation of non-digestible substrates of the diet and the mucus produced by the epithelium with the production of short-chain fatty acids (acetate, propionate and butyrate) favoring the recovery and absorption of calcium, iron and magnesium, in the regulation of glucose metabolism reducing postprandial glycemia, as well as the synthesis of vitamin $\mathrm{K}$ and those of group B.

LARA-LÓPEZ, Ivonne Montserrat, SANTIESTEBAN-LOPEZ, Norma Angélica, CERÓN-CARRILLO, Teresa Gladys and MORALESPAREDES, Yesbek Rocío. The role of probiotics in times of the COVID-19 pandemic. ECORFAN Journal-Republic of Guatemala. 2020 


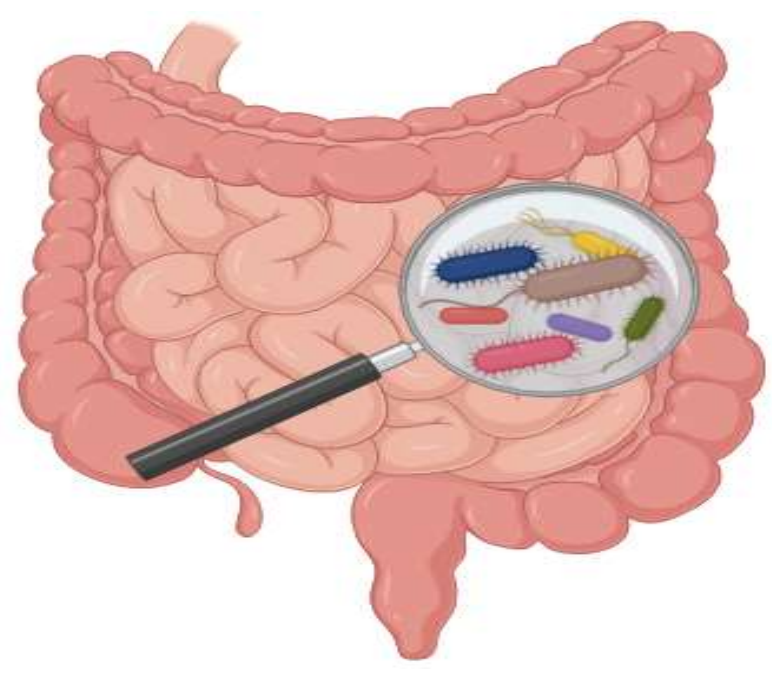

Figure 4 Illustration of the intestinal microbiota Source: Own elaboration with data from: https://biorender.com/

Some benefits include improvement in infectious diseases, chronic intestinal diseases such as ulcerative colitis, immunomodulation, cardiovascular diseases, non-insulin-dependent diabetes mellitus, obesity, osteoporosis, and even cancer.

These effects may be due directly or indirectly to the regulation of the intestinal microflora or the immune response. Among the probiotic bacteria most used for human consumption are the so-called LABs, which include the following: Lactobacillus acidophilus, L. plantarum, L. casei, L. casei spp rhamnosus, $L$. delbrueckii spp bulgaricus, $L$. fermentum, L. reuteri, Lactococcus lactis spp lactis, Lactococcus lactis spp. cremoris, Bifidobacterium bifidum, $B$. infantis, $B$. adolecentis, B. longum, B. breve, Enterococcus faecalis, Enterococcus faecium, among others.

One way of acting of probiotics to achieve a good state of health of the individual is through the resistance granted against the invasion of pathogenic microorganisms, which is achieved through the generation of antimicrobial substances such as lactic acid and other short chain acids, metabolites such as hydrogen peroxide and diacetyl (GonzálezMartínez, et al. 2003). The main molecules that are a product of the metabolic activity of BAL bacteria are: ethanol, lactate, acetate, folic acid, pyruvate, succinate, which can be metabolized to produce short-chain fatty acids SCFA.
For example, Lactobacillus gasseri culture supernatants have been found to inhibit the growth of Escherichia coli, Bacillus cereus, and Pseudomona aeruginosa, an important microbiota that is harmful to humans (MedinaTorres, 2014).

\section{Mechanism of action of probiotics}

Upon entering our body, probiotics are free to exert actions, which include induction at a $\mathrm{pH}$ lower than 4, inhibition of the growth of pathogenic bacteria, production of lactic acid, decrease in intestinal permeability, increase in lactase activity, competitive effect. in other pathogenic bacteria, effects on immunity. The clinical utility of probiotics is different in each case and depends on the strain and the administered dose. Lactobacilli and bifidobacteria can secrete natural antibiotics with a broad spectrum of activity, such as lactokines, helveticins, curvacins, nicines, and bifidocins, and studies have shown their action on the immune system (Rondon, et. al 2015). Lactobacilli and bifidobacteria are Gram positive, whereas bifidobacteria are anaerobic and are microaerophilic. Currently there are some clinical studies in humans that support its usefulness as adjuvants in the medical treatment of various diseases (Figure 5).

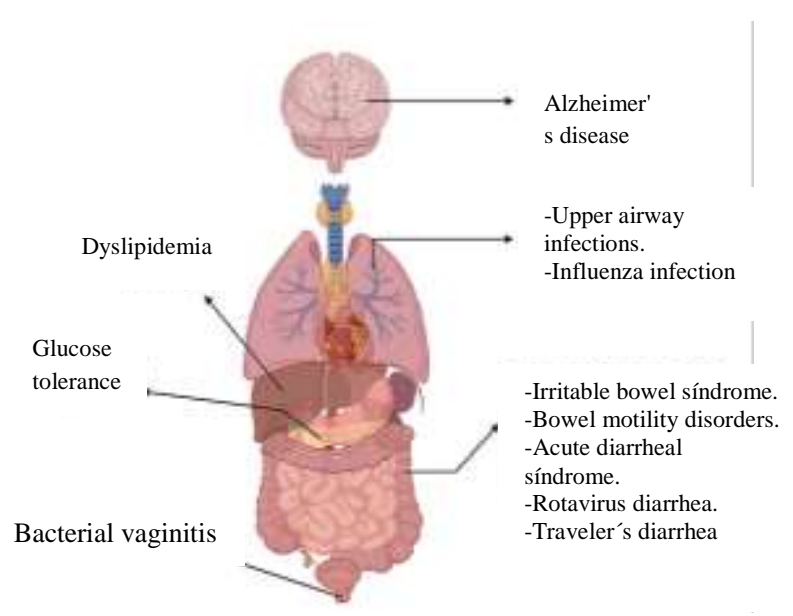

Figure 5 Diseases in which probiotics have a beneficial effect. Source: Adapted from (Ortíz, 2018)

Own elaboration with data from https://biorender.com/

There is extensive tissue that covers the surface of the digestive system and forms the first immune barrier, which defends and maintains the homeostasis of the internal environment. This barrier is composed of mucus and an underlying epithelium. 
Below this barrier we find epithelial and dendritic cells and intra-epithelial lymphocytes, located between the enterocytes. This barrier is capable of distinguishing between own and innocuous antigens and pathogens, developing an immune response against them if necessary. By virtue of an adequate distinction between pathogens and self antigens, an optimal balance between immunity and tolerance will take place, so that food allergies and / or exacerbated inflammatory responses do not develop.

This immune system is known as mucosa-associated lymphoid tissue. This tissue that lines the intestine, is distinguished in turn into follicular aggregates called Peyer's patches, and isolated lymphoid follicles, the latter being the ones that are mostly covering the large intestine (Trillo-Osuna, 2018).

Our microbiota performs two main types of functions: digestive and protective, guided by a series of mechanisms. For example, the digestive function is performed by generating essential nutrients such as vitamins and some amino acids or facilitating the use of indigestible nutrients, such as certain sugars. And on a defensive level, both microbiota bacteria and probiotics can interact with the three protective lines available to the body at the intestinal level: the first or microbiological line, the second or barrier line, and the third or immune line ( PérezCano, 2016). In addition, microbiota bacteria and some groups of probiotics can produce antimicrobial compounds providing an environment not suitable for pathogens. They generate a multitude of substances with antibiotic capacity such as bacteriocins, hydrogen peroxide or organic acids.

\section{Bacteriocins}

Bacteriocins are protein toxins synthesized by bacteria. There are numerous bacteriocins produced by LABs and each one has particular inhibition spectra, this characteristic is exploited in the food industry to use them in various ways. They have antimicrobial activity even in pathogenic bacteria, with great potential for the food industry since they can be used as pure biological preservatives that at one point could even replace chemical preservatives since they have the advantage of being proteins that, when biodegraded, do not form secondary compounds.
Given the importance that probiotics are currently taking as functional foods and in particular the bacteriocins they produce, it is interesting to recognize some characteristics of these substances and their antimicrobial properties (González-Martínez, 2003). Among the bacteriocins produced by lactic acid bacteria, 2 groups can be distinguished: The first are those that are active against related strains or species (lactococins A, B, M and G, lactacin B and helveticin J, among others) and the The second consists of those that inhibit a much broader group of microorganisms, including those that include pathogens and food modifiers (Jaramillo-Giraldo, 2010). Advances in the study of antimicrobial efficacy and spectrum of action in the area of $\mathrm{LAB}$ bacteriocins are attractive in a world in which antimicrobial resistance constitutes a global problem of great relevance to public health.

\section{Role of probiotics in the immune system}

It has been said that the stomach is like "our second brain", the reality is not very far from the concept since abundant complex reactions are carried out in this system, it commands activities with specific objectives, both of our diet, as well as regulation of other issues, therefore, the intestine plays a very important role that has an impact on our tolerance and defense mechanism against diseases and memory maintenance of the immune response in the body.

Consequently, it is established that probiotics are not only limited to the intestinal flora but that they can also modulate the systemic immune response, showing beneficial effects in infectious diseases (example: salmonellosis and pneumococcal lung infections), as well as in allergies and asthma . Dr. Cani (2015) states: "Probiotics or prebiotics can be ingested to improve the development of some diseases or even to stimulate the immune system. Our daily life brings us great levels of stress and we can never be sure when we are going to get sick. Therefore, the possibility of reducing or preventing symptoms by taking probiotics and prebiotics is very attractive to me".

The World Health Organization (WHO) has decreed that the effects of probiotics are specific according to the type of bacteria and not all probiotics are the same, nor do they have the same benefits on the body. 
For this reason, it is not possible to generalize in their functions and must be analyzed strain by strain. The microorganisms of the microbiota constitute a protective barrier in the mucosa of individuals since they confer a first line of defense against pathogens: the microbiological barrier. This barrier of microorganisms generates the well-known mechanism of microbial antagonism (Figure 6), that is, it prevents the settlement of microorganisms external to our system, which can be pathogenic and can act on our mucous membranes.

On the one hand, the microbiota and certain probiotics establish a relationship of direct competition with pathogens for the areas of attachment to the surface of the mucosa: if the microbiota occupies the intestinal space, interaction by other microorganisms is prevented. And, if the probiotics or the microbiota consume the nutrients, they will no longer be available for the use of pathogenic microorganisms and thus be able to stop their development and activity.

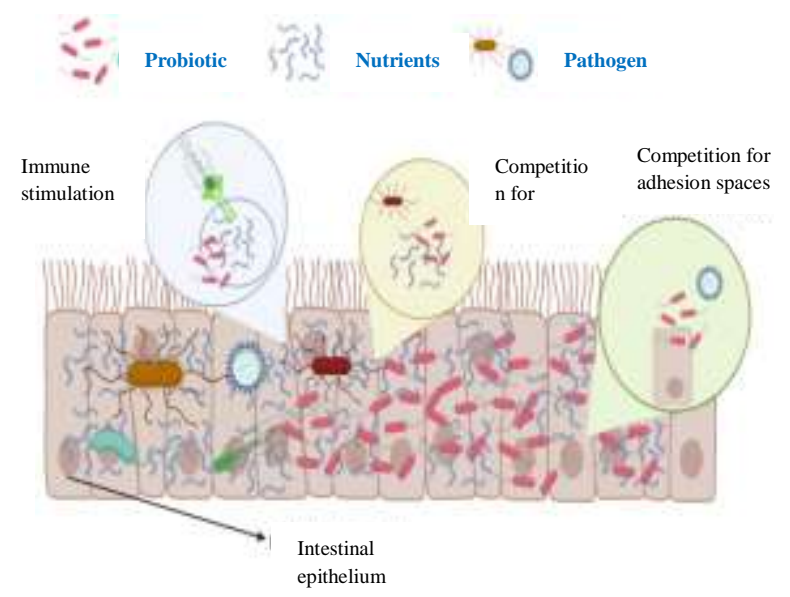

Figure 6 Microbial antagonism of probiotics and pathogens in the intestinal epithelium

Source: Adapted from (News, 2015). Own elaboration with data from https://biorender.com/

There are studies that affirm the fact that certain probiotics can improve the answer to the vaccine against influenza; with revised experimentation and meta-analysis, it was concluded that, when administered by the digestive route, they improved seroconversion and seroprotection in vaccinated adult patients. That is, the protection obtained by the vaccine was verified, and they showed significant improvements against the H1N1 strain.
The effective probiotic bacteria in the study were different strains of $L$. fermentum, $L$. casei, L. casei Shirota, L. paracasei, $L$. rhamnosus $G G, L$. plantarum, B. longum and B. animalis (Lei et al. 2017 ).

The mechanisms by which these microorganisms exert their immune effect is the favorable induction of activity in phagocytes and NK cells, in addition to the secretion of $\operatorname{IgA}$ in mucosa. Furthermore, the peptidoglycan components of probiotic bacteria and their metabolites, short chain fatty acids, act on the epithelium and the intestinal microbiota, modulating the immune response. Increasing mucosal IgA secretion is important in preventing influenza virus infection. In another review, it is highlighted that the effect of probiotics was effective, although modest; This was carried out for children and adults, in two meta-analyzes the effect of its oral administration on infections of the upper respiratory system was investigated and they concluded that they confer benefits in terms of prevention and duration of the disease.

In this case, preparations of different strains were used, but an effect was specifically reviewed in Lactobacillus and Bifidobacterium. This review provides evidence that probiotics reduce the duration of illness in otherwise healthy children and adults. (King et al. 2014). Therefore, it is important to emphasize that the use of LABs could support infections caused by SARS-CoV. One more experiment is that probiotics were applied in rodents by different administration routes, this has allowed to discover additional benefits. A strain of $L$. rhamnosus was given sublingually and this conferred protection against influenza virus infection, achieving an anti-inflammatory effect (Barahona-Garrido, 2020).

\section{Pilot survey}

According to the bibliographic review described above, it was decided to carry out a pilot survey to obtain a broader and more accurate picture of the opinion of people interested in the benefits that probiotics provide, for this particular case, to strengthen the immune system and in this way prevent the spread of COVID-19 disease, as well as other infections.

The survey was carried out in a Google form, and distributed to a total of 62 people between 15 and 53 years old. 
Now, the questions with their corresponding answers are displayed:

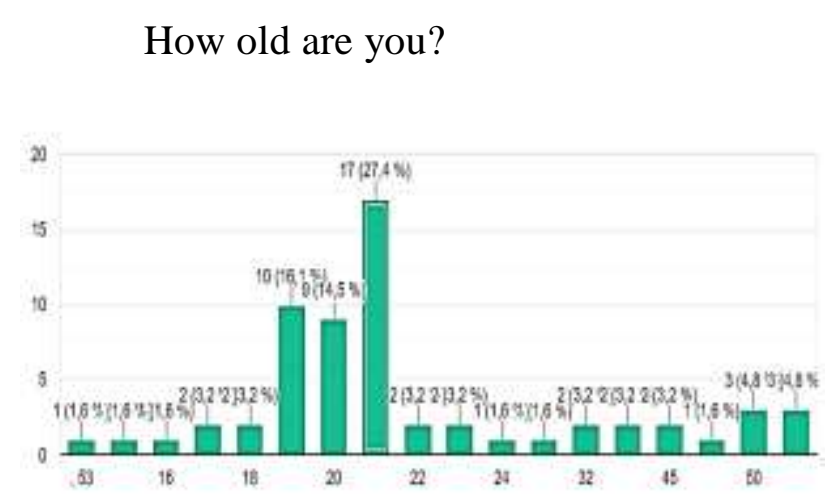

\section{Graph 1}

Source: Own Elaboration

Do you know the benefits of probiotics?

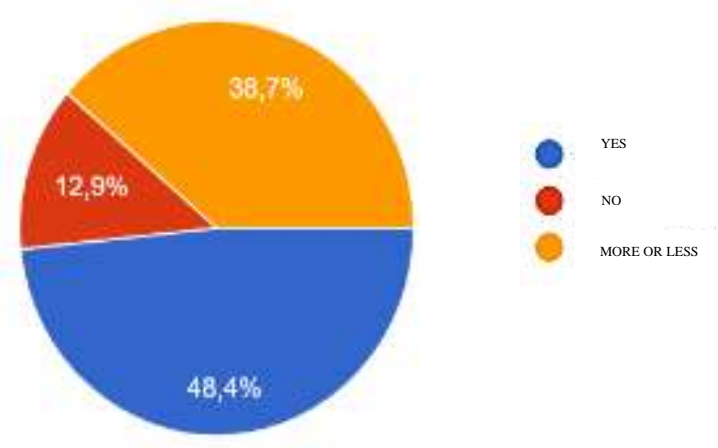

\section{Graph 2}

Source: Own Elaboration

We note that of the 62 people surveyed, $48 \%$ answered yes, and $39 \%$ answered more or less, the rest said no. them?

In what presentation do you consume

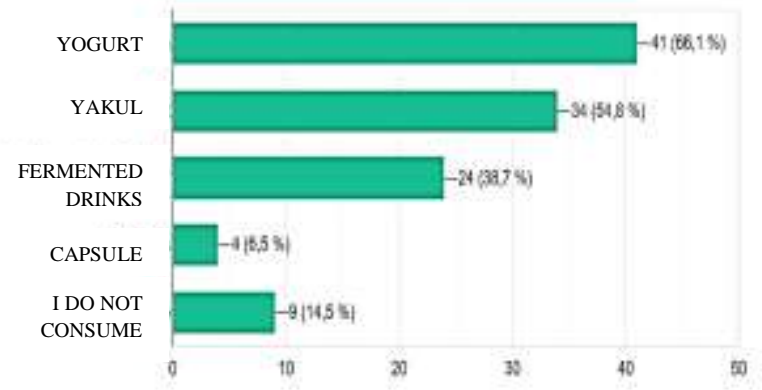

Graph 3

Source: Own Elaboration

It is reflected that yogurt and Yakult are the most consumed beverages of those surveyed. system?

How would you rate your immune

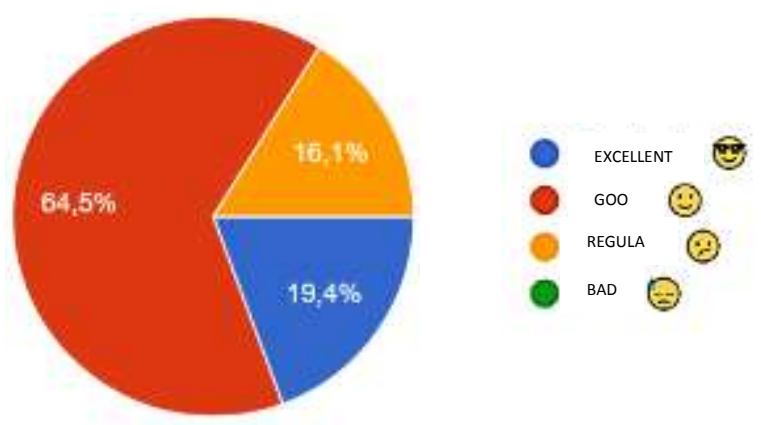

\section{Graph 4}

Source: Own Elaboration

More than half, $64.5 \%$ rate their defenses as good, $19.4 \%$ think it is excellent, while $16 \%$ rate it as fair.

From this pandemic, did you start to take better care of your diet?

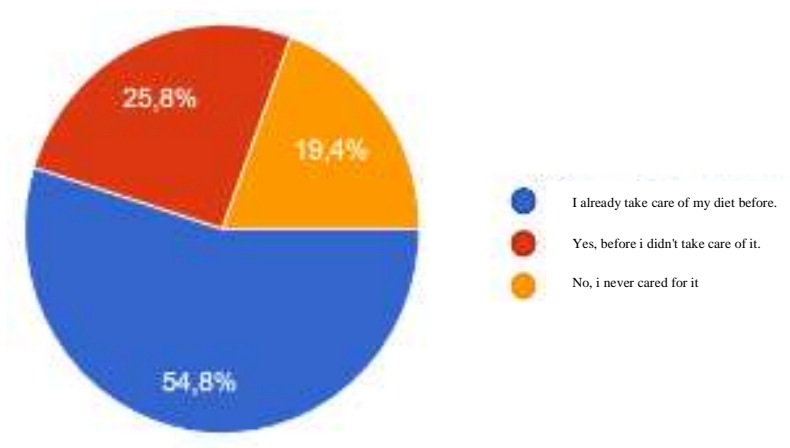

\section{Graph 5}

Source: Own Elaboration

We observed that 34 of the 62 surveyed people took care of the way they eat, 12 of them do not take care of it so far and 16 started with good habits.

If your previous answer is affirmative, what food measures do you implement in your daily diet?

Some of the answers:

- $\quad$ Low-fat foods

- I increased the consumption of vegetables

- Fruits and vegetables at all meals, reduced sugars

- $\quad$ Minimal in fat and sugar

- $\quad$ Eat balanced and reduce sugars and saturated fats

- $\quad$ Low carbohydrate intake

LARA-LÓPEZ, Ivonne Montserrat, SANTIESTEBAN-LOPEZ, Norma Angélica, CERÓN-CARRILLO, Teresa Gladys and MORALESPAREDES, Yesbek Rocío. The role of probiotics in times of the COVID-19 pandemic. ECORFAN Journal-Republic of Guatemala. 2020 
- $\quad$ Drink more water and eat less

- Consumption of the 3 macronutrients in a proportional way

- $\quad$ Fresh foods low in fat and sugars

- $\quad$ More fiber and protein

- $\quad 3$ full meals and 2 fruit or seed snacks, no soft drinks or juices, no fried foods, spinach every day

\section{- $\quad$ I take vitamin B12}

- A balanced diet

- $\quad$ Eat more vegetables and fruits, lower sugars and salt

- $\quad$ I try not to eat highly processed foods, or add salt or sugar to food

- $\quad$ Lots of fruits and vegetables

- Water intake and balance in food groups

Various responses were shared about their eating habits.

Do you consume any type of vitamins or another type of drug to strengthen your defenses?

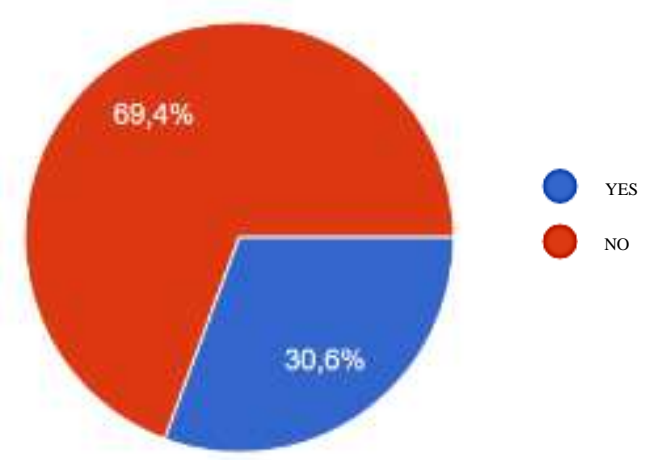

Graph 6

Source: Own Elaboration

The large percentage $(69.4 \%)$ of people who do not consume any vitamin or any defensestrengthening drug is observed.

If it was scientifically proven that probiotics help strengthen your immune system and thus prevent you from getting sick with COVID-19, would you consume more of them?

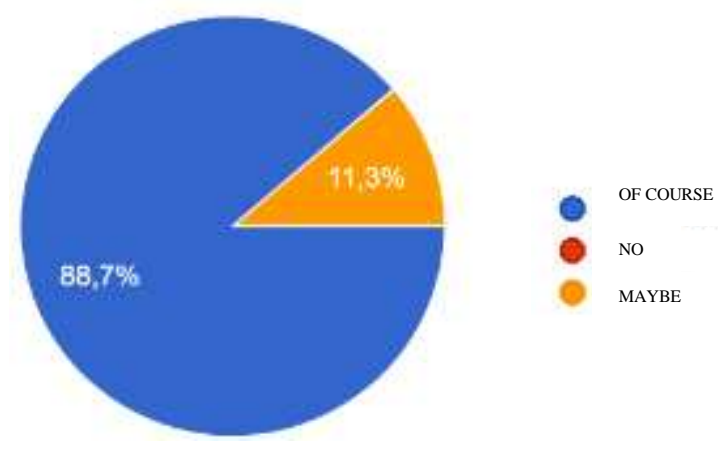

Graph 7

Source: Own Elaboration

It is strongly appreciated with an affirmative response from a total of 55 people of the 62 respondents and only 7 responded perhaps.

\section{Discussion}

The people surveyed were of legal age except for 4 of them, mostly young adults around 20 years old and others between 40 and 53 years old, so we see the population surveyed is very varied. Also the eating habits will be different. Almost $50 \%$ do know about the effects of probiotics, and a total of only 8 people are not aware of them.

It is known that there are various presentations where we can find probiotics, such as dairy products, fermented drinks or capsules. Most consume yogurt, yakult and various beverages, and surprisingly only 4 people consume capsules with probiotic strains and 9 of them do not consume any of the options, with this we can infer that it is a population with a very diverse microbiota each. It is also worth noting that they were questioned about their immune system, based on their experience just over $60 \%$ rated it as "good".

As a result of this pandemic, a sale of health care products has been unleashed, in addition to healthy eating habits have been acquired, and in response to this, 55\% responded that they had already taken care of their habits before, $26 \%$ They adopted habits from what happened and $19 \%$ do not have the culture of it. After that, some people commented about their habits, among them the consumption of fruits, vegetables, fibers, the limitation of high carbohydrate and lipid intake, also the intake of more water. 
To reinforce this, the consumption of vitamins and minerals or prebiotics is expected, to increase defenses and complement healthy eating habits, but this was not reflected, since $70 \%$ do not take any type of drug or vitamin for this. Finally, without having proven results to date, the majority $(89 \%)$ of the respondents expressed that they would be willing to consume probiotics to strengthen their immune system, leading to no more infections of COVID-19 or any other disease.

\section{Conclusion}

The efficacy of most vaccines is high, however, they are designed to generate an immune response that will protect the vaccinated person from future exposures to the disease. But individual immune systems are so different that, in some cases, the person's immune system will not generate an adequate response. As a result, you will not be protected effectively after vaccination. That said, we can see examples of studies carried out against the H1N1 influenza disease, based on the use and application of probiotics, resulting in beneficial effects.

This makes clear a panorama that it would be very useful to study these microorganisms because it has sufficient bases to justify the investigation of probiotics in the face of the COVID-19 disease, and in that way we can prevent, which is the first option. According to the survey carried out, it was found that thanks to this research project carried out in the Dolphin Summer it was possible to publicize the benefits of probiotics to increase immunity, and avoid bacterial and viral infections such as COVID 19, for what its consumption could help us not to get sick, or lessen the symptoms of the disease.

\section{References}

Alcántara-Montero A, e. a. (2020). Posibles factores protectores de la infección por SARS$\mathrm{CoV}-2$ en una paciente vulnerable: a propósito de un caso. Semergen.

Barahona-Garrido. (03 de Julio de 2020). ¿Se debe investigar la utilidad de los probióticos en la COVID-19? Obtenido de El probiótico: https://www.elprobiotico.com/investigar-

probioticos-covid-19/
Cani. (04 de Noviembre de 2015). Entrevista a Patrice D. Cani: "Los probióticos y los prebióticos pueden mejorar o prevenir el desarrollo de ciertas enfermedades". Obtenido de Gut Microbiota for Healt: https://www.gutmicrobiotaforhealth.com/es/losprobioticos-y-los-prebioticos-pueden-mejoraro-prevenir-el-desarrollo-de-ciertasenfermedades/

Cortés, M. (2020). Coronavirus como amenaza a la salud pública. Carta al editor. . Rev. méd. Chile, 123-129.

Gastroenterología, G. M. (2017). Probióticos y prebióticos. $W G O$.

González-Martínez. (2003). Bacteriocinas de probióticos. Rev Salud Publica Nutr.

Guarner, F. (11 de Mayo de 2020). EL PROBIÓTICO. Obtenido de https://www.elprobiotico.com/probioticos-ycovid-19/

Jaramillo-Giraldo. (2010). Evaluación de la producción de bacteriocinas a partir de Lactobacilosy Bifidobacterias. Revista Venezolana de Ciencia y Tecnología de Alimentos., 193-209.

King. (2014). Effectiveness of probiotics on the duration of illness in healthy children and adults who develop common acute respiratory infectious conditions: a systematic review and meta-analysis. Br J Nutr., 41-54.

Lei, e. a. (2017). Effect of Probiotics and Prebiotics on Immune Response to Influenza Vaccination in Adults: A Systematic Review and Meta-Analysis of Randomized Controlled Trials. . Nutrients.

Lenoir-Wijnkoop, I. (2019). Probiotics Reduce Health Care Cost and Societal Impact of FluLike Respiratory Tract Infections in the USA: An Economic Modeling Study . Frontiers in Pharmacology, 980.

Medina-Torres. (2014). El uso de probióticos y los beneficios sobre el sistema inmune. Revista de educación bioquímica, 77-85. 
News, N. (06 de Junio de 2015). Rev. Nutri News. Obtenido de Probióticos, Prebióticos y Simbióticos en nutrición y salud animal: https://nutricionanimal.info/probioticosprebioticos-y-simbioticos-en-nutricion-y-saludanimal/

Ortíz, G. (2018). Probióticos ¿coadyuvantes en el tratamiento médico? Medicina Interna de México.

Osuna, T. (2018). Probióticos y su papel en la defensa inmunitaria. Madrid: Facultad de Farmacia Universidad Complutense.

Palacios-Cruz. (2020). COVID-19, una emergencia de salud pública mundial. Rev Clin Esp.

Pérez-Cano. (16 de Octubre de 2016). Probióticos y sistema inmunitario. Obtenido de Lactoflora:https://www.lactoflora.es/probiotico s-y-sistema-

inmunitario/\#: :text=En\%20resumen\%2C\%201 os\%20probi\%C3\%B3ticos\%2C\%20a,o\%20inap ropiadas $\% 20$ como $\% 201$ as $\% 20$ alergias.

Rojas-Zumarán, V. e. (2020). COVID-19: el enigma de los caminantes asintomáticos. Patología Clínica y Medicina de Laboratorio.

Rondon. (2015). Probióticos: generalidades. Archivos Venezolanos de Puericultura y Pediatría.

Serrano-Cumplido A, e. a. (2020). COVID-19. La historia se repite y seguimos tropezando con la misma piedra. Semergen.

Silva Belasco, A. G., \& Dezoti da Fonseca, C. (2020). Coronavirus 2020. Revista Brasileira de Enfermagem.

Xie, M., \& Quiong, C. (2020). Insight into 2019 novel coronavirus - An updated interim review. International Journal For Infectious Diseases, 119-124. 